\title{
Development of Measurement Techniques for Siloxanes in Landfill Gas
}

\author{
Mirosława Kaszubska, Małgorzata Wzorek* \\ Opole University of Technology, Department of Process Engineering, Opole, Poland
}

\begin{abstract}
In Poland, the biogas obtained from municipal solid waste landfills is most frequently used in biogas systems. In combustion of biogas contaminated with siloxanes, they transform and decompose to silica and silicate deposits, which affect the proper operation of power supply devices, i.e. electric generation systems or boilers. The study aimed to determine the optimal methods for the collection of representative biogas sample for gas chromatography (GC) analysis. The main tasks included the selection of the most favourable sampling conditions for siloxane sorption in a given sorbent, i.e. sampling time, gas flow speed and sorbent volume. The study regarded the landfill gas from the Municipal Landfill located in the city of Opole in Poland. Research showed the presence of organosilicon compounds in the tested biogas but their concentration was low. That's way the landfill gas can be successfully used for energy purposes without compromising the equipment caused by the presence of siloxanes
\end{abstract}

Keywords: Fuel, Biogas, Landfill, Impurities, Siloxanes

\section{Introduction}

The economic and commercial development results in increasing need for power, and the sources of fossil fuels keep shrinking. Therefore, important aspects for the contemporary world and future generations are care for the natural environment, search for new and renewable sources of energy as well as observance of sustainable development rules in waste management.

Biogas may be the key to solve these problems. It is a product of fermentation process taking place in organic matter. Its content differs, depending on the type of reactants participating in the process. We can distinguish the following types of biogas generated from [1]:

- Landfill gas.

- Wastewater treatment plants.

- Agricultural waste.

The landfill gas is a renewable fuel source formed from organic matter present in the waste mass collected on landfills. It is composed mostly of methane and carbon dioxide as well as various trace contaminants, e.g. organosilicon chemical compounds. These compounds, referred to as siloxanes, manifest multiple valuable properties, resulting in high willingness to use them in the industry.

Since the use of siloxanes is becoming more and more common, their concentration in the waste and, in consequence, in the biogas increases. In case of use of biogas for power generation purposes, their valuable properties become a threat for the devices using biogas as their fuel. They can cause, inter alia, increased inspection, failure and damage rate. Furthermore, siloxanes have a negative effect on the natural environment and living organisms $[2,3]$.

Therefore, studies of siloxanes as well as continuous improvement of the methods of sampling, determination and removal of siloxanes are essential not only for the industry.

\section{Siloxanes Characteristics}

The distinctive feature of siloxanes is their specific structure containing alternating atoms of oxygen and silicon. Functional groups can be bound to the silicon atoms. In terms of structure, siloxanes can be divided into chain and cyclic types.

Fig. 1 presents the linear and ring structure of these chemical compounds and review of the parameters of the most common siloxanes is presented in Table 1.

${ }^{*}$ Corresponding author. Tel.: +48 774498779

E-mail: m.wzorek@po.opole.pl

(C) 2018 International Association for Sharing Knowledge and Sustainability

DOI: $10.5383 /$ ijtee.16.02.004 

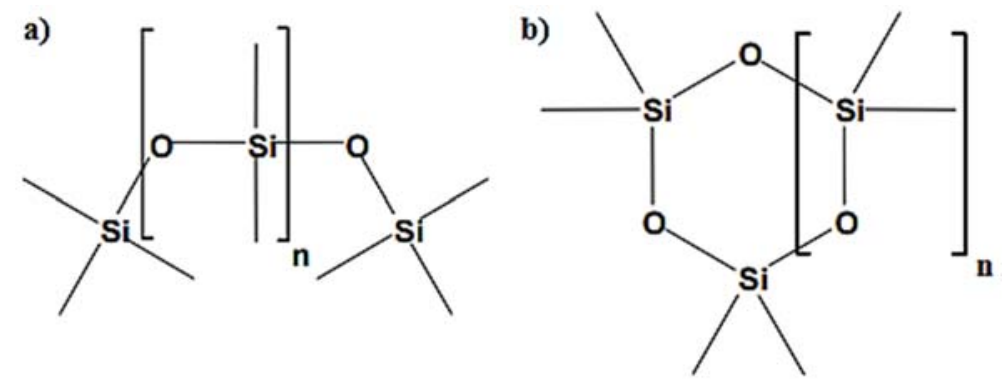

$$
\begin{array}{ll}
\mathrm{n}=0 \text { hexamethyldisiloxane } & \mathrm{n}=1 \text { hexamethylcyclotrisiloxane } \\
\mathrm{n}=1 \text { octamethyltrisiloxane } & \mathrm{n}=2 \text { octamethylcyclotetrasiloxane } \\
\mathrm{n}=2 \text { decamethyltrisiloxane } & \mathrm{n}=3 \text { decamethylcyclopentasiloxane }
\end{array}
$$

\begin{tabular}{|c|c|c|c|c|}
\hline Organic silicon compound & Abbreviation & $\begin{array}{l}\text { Vapour pressure } \\
\text { at } 25^{\circ} \mathrm{C}(\mathrm{mmHg})\end{array}$ & $\begin{array}{c}\text { Boiling } \\
\text { temperature }\left({ }^{\circ} \mathrm{C}\right)\end{array}$ & $\begin{array}{c}\text { Water } \\
\text { solubility } 25^{\circ} \mathrm{C} \\
(\mathrm{mg} / \mathrm{L})\end{array}$ \\
\hline Hexamethyldisiloxane & L2 & 31.00 & 106.67 & 0.9300 \\
\hline Hexamethylcyclotrisiloxane & D3 & 10.00 & 135.00 & 1.5600 \\
\hline Octamethyltrisiloxane & L3 & 3.90 & 152.78 & 0.0350 \\
\hline Octamethylcyclotetrasiloxane & D4 & 1.30 & 175.56 & 0.0560 \\
\hline Decamethyltetrasiloxane & L4 & 0.55 & 193.89 & 0.0067 \\
\hline Dodecamethylpentasiloxane & L5 & 0.07 & - & 0.0003 \\
\hline Dodecamethylcyclohexasiloxane & D6 & 0.02 & 245.00 & 0.0050 \\
\hline Decamethylcyclopentasiloxane & D5 & 0.40 & 211.11 & 0.0170 \\
\hline Trimethylsilanol & TMS & - & 98.89 & 3500 \\
\hline
\end{tabular}

Fig. 1. Siloxanes structure: a) chain, b) cyclic

Table 1. Characteristics of biogas of various origin $[4,5]$

Organosilicon chemical compounds manifest hydrophobic properties, low water solubility and high non-polar solvent solubility. They are characterised with high vapour pressure, low viscosity, low surface tension and, furthermore, high oxidation resistance, high attenuation properties and resistance to UV radiation. They preserve their properties even in temperature increase conditions. They are high volatility substances, thus penetrating from the waste mass or sewerage to the biogas. Moreover, volatility of siloxanes significantly hinders their sampling and determination.

Due to their properties, their applicationis becoming increasingly common in such various industries as: cosmetic, chemical, pharmaceutical and medical (Table 2).

Table 2. Use of siloxanes and silicones

\begin{tabular}{cc}
\hline Sector & Products \\
\hline Medical & Implants, tracheostomy tubes \\
Chemical & Washing agents, paper, glue, paint, shoe polish \\
Cosmetic & Creams, shampoos, nail polish \\
Automobile & Greases, varnishes \\
\hline
\end{tabular}

Landfill biogas is less rich in siloxanes, and D4 and D5 compounds account for slightly over $50 \%$ of their total concentration [8].

It is estimated that the siloxanes content in older the landfill, the lower the siloxanes concentration [8].
On the other hand, the agricultural biogas is free from this type of contamination.

The exemplary concentrations of siloxanes in biogas of various origin are presented in Table 3.

Table 3. Siloxanes concentrations in different locations $[7,9,10,11]$

\begin{tabular}{ccc}
\hline Target & Location & $\begin{array}{c}\text { Total siloxanes } \\
\text { concentration }\left(\mathbf{m g} / \mathbf{m}^{3}\right)\end{array}$ \\
\hline Bioreactor & Switzerland & 25.1 \\
Bioreactor & Germany & 59.8 \\
Bioreactor & Belgium & 20.0 \\
Bioreactor & Finland & 29.6 \\
Bioreactor & UK & 400.0 \\
Bioreactor & Poland & 8.5 \\
Landfill & Poland & 5.5 \\
Landfill & Germany & 36.3 \\
Landfill & Austria & 9.3 \\
Landfill & Finland & 6.69 \\
\hline
\end{tabular}

Depending on the reactants in the methane fermentation process, the amount and type of siloxanes in the biogas can vary. The highest siloxanes count can be found in biogas from sludge from wastewater treatment plants - D4 and D5 compounds account for over $90 \%$ of their concentration $[6,7]$. 


\subsection{Technological Aspects of Disposal of Biogas Contaminated with Siloxanes}

Combustion of biogas that is contaminated with siloxanes causes their transformation into the so-called deposits. They form a deposit layer that adheres to the hot metal surfaces of devices, causing disturbances in operation, reduction of efficiency of energy recovery from biogas as well as extensive damage.

The consequences involve servicing and operating issues, entailing excessive costs of power generation from biogas. Furthermore, removal of these deposits using chemical or mechanical methods is almost impossible [11]. In general, the silicon content from deposits found in facilities utilizing biogas from anaerobic digesters was lower than those operated with landfills gas. The difference was made up with higher phosphorus, sulfur and calcium content in the deposits from the engines operated with digester gas [12].

The deposits are composed mostly of silica and silicates in form of white solids with high hardness and sand-line structure (Fig. 2).

Silica deposits are good heat insulators which results in temperature increase and heat exchange process inhibition in recuperators. Due to abrasive properties of silica, the rotor blades are frequently damaged due to their excessive abrasion, with crankshaft and bearings also being exposed to potential damage.

In piston engines, the deposit layer covers both valves and cylinder walls. The combustion chamber can suffer from geometry distortion, causing an increase of carbon dioxide and formaldehyde emission. Hard deposits can cause scratches and cuts on the bush surface $[5,7,14]$.

Use of piston engines requires proper lubrication between the bush surface and the piston ring. The deposits absorb the lubricant, thus preventing formation of the lubrication layer which can result in adhesion wear and tear.
Silicon compounds can also accumulate under the outlet valves, which can cause valve burns and, thus, decrease of engine capacity [15].

\subsection{Measurement Methods}

The interest in siloxanes has begun relatively recently, both in terms of their application and impact on industrial devices, natural environment and living organisms. There is no golden method to sample these compounds from the biogas stream or a perfect analytical method of their determination. The research in this area is still being conducted and the best solution is yet to be found.

Table 4 presents the most common methods used to collect siloxanes from the biogas stream.

These methods can be divided into direct and indirect methods. The former ones involve sorption processes with use of a solid sorbent - adsorption, or liquid sorbent - absorption. In terms of sample collections, the direct, for example canister method is simple and fast requiring only 16 seconds to passively fill a $6 \mathrm{~L}$ canister.

The indirect, for example impinge method requires experience with solution sampling and patience since sampling intervals can last up to three hours [15].

It is recommend to employ intermediate methods due to the possibility of sample enrichment. Moreover, the most common sorbents are organic solvents as they manifest higher affinity to silicon compounds than solid sorbents. An important element affecting the efficiency of intermediate methods employing liquid sorbents is their continuous optimization, i.e. providing for the gas flow, sampling time and volume of the applied sorption solvent $[11,16]$.

The indirect, for example impinge method requires experience with solution sampling and patience since sampling intervals can last up to three hours [15].
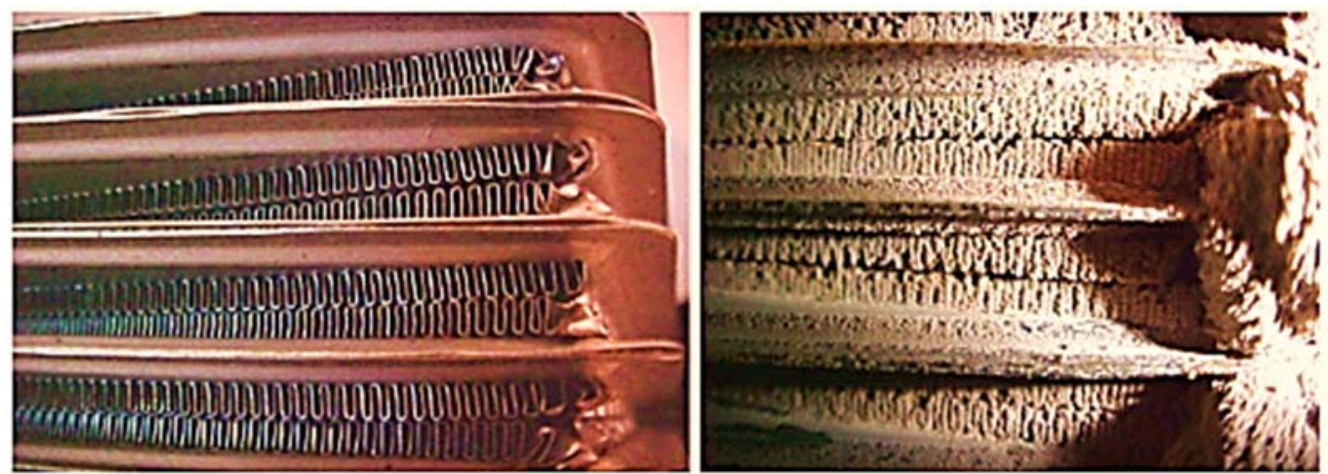

Fig. 2. Silicate layers present in a microturbine [13]

Table 4. Sampling techniques of gaseous siloxane $[8,12,16$

\begin{tabular}{|c|c|c|c|}
\hline Method & Material & Advantages & Disadvantages \\
\hline Adsorbent & $\begin{array}{l}\text { Activated carbon } \\
\text { Tenax } \\
\text { XAD }\end{array}$ & $\begin{array}{l}\text { Sample concentration possible, simple, acceptable D4 } \\
\text { recovery }\end{array}$ & $\begin{array}{l}\text { Time consuming, additional devices } \\
\text { required }\end{array}$ \\
\hline Impinger & $\begin{array}{l}\text { Methanol } \\
\text { n-hexane } \\
\text { Acetone }\end{array}$ & $\begin{array}{l}\text { Perform better than canisters for less volatile } \\
\text { compounds (D4, D5, D6), 80\% recovery for L2 and } \\
\text { L3 }\end{array}$ & $\begin{array}{l}\text { Time consuming, additional devices and } \\
\text { ice bath required }\end{array}$ \\
\hline Canister & Metal canister & $\begin{array}{c}\text { Simple, quick passive sampling, better D3 recovery } \\
\text { performance than impingers }\end{array}$ & $\begin{array}{c}\text { Sample concentration not possible, erratic } \\
\text { readings for D4, D5, D6 }\end{array}$ \\
\hline Tedlar bags & Tedlar® bag & Low purchase/shipping cost, availability & Sample concentration not possible \\
\hline
\end{tabular}


It is recommend to employ intermediate methods due to the possibility of sample enrichment. Moreover, the most common sorbents are organic solvents as they manifest higher affinity to silicon compounds than solid sorbents.

An important element affecting the efficiency of intermediate methods employing liquid sorbents is their continuous optimization, i.e. providing for the gas flow,

sampling time and volume of the applied sorption solvent $[11,16]$.

The analytical methods employed to determine trace contamination present in the biogas involve atomic absorption spectrometry and gas chromatography combined with various types of detectors, e.g.:

- $\quad$ Mass spectrometry - MS.

- Flame ionization detection - FID

- Photoionization detection - PID.

\section{Materials and Methods}

\subsection{Biogas Sampling Locations}

The study regarded the landfill gas from the Municipal Landfill located in the city of Opole, Poland. It was obtained from a landfill with area of $6.4 \mathrm{ha}$. Biogas is used to generate electricity about 2,200 MWh/year. Averaged parameters of the examined biogas are presented in Table 5 .

Table 5. Averaged composition of the tested biogas

\begin{tabular}{ccc}
\hline Ingredient & Unit & Value \\
\hline $\mathrm{CH}_{4}$ & vol. \% & 47.8 \\
$\mathrm{CO}_{2}$ & vol. \% & 24.0 \\
$\mathrm{O}_{2}$ & vol. \% & 1.9 \\
$\mathrm{H}_{2} \mathrm{~S}$ & ppm & 79.0 \\
\hline
\end{tabular}

\subsection{Samples Collection}

The absorption method was used for the purpose of collection of environmental samples. XAD2 polymer resin was used as the solid sorbent, filling the glass tubes.

Furthermore, the sampling installation consists also of a biogas pump, gas meter and cooler. The sampling parameters are presented in Table 6.

Table 6. Sample collection specification

\begin{tabular}{cc}
\hline Specifications & Adsorbent Method \\
\hline Utilities & Glass tube, size $155 \times 5 \mathrm{~mm}$ \\
& XAD2 polymer resin \\
Impinger solution & $24-100 \mathrm{~L}$ \\
Sampling Volume & $35-90 \mathrm{~L} / \mathrm{h}$ \\
Sampling rate & $20-60 \mathrm{~min}$ \\
Sampling time & Closed tubes, room temp. \\
\hline
\end{tabular}

\subsection{Analytical Detection of Siloxanes}

The analytical evaluation of the samples was performed using the gas chromatograph System 7890B Agilent Technoligies combined with a flame ionizing detector. Instrument and standard specification was presented in Table 7 .

\section{Results and Discussion}

According to Wheless and Pierce [17], the landfill gas contains mostly D5 and D4 compounds. Furthermore, it can contain small amounts of D3, D6 and L2 - L5 compounds [18]. The conducted analyses showed that cyclic siloxanes, i.e. D4 and D3, and then L3 and D5, have the highest share in the content of the landfill biogas.

Additionally, summed up concentrations of these compounds are significantly lower than values specified by other authors (Table 3). This fact can result from the old age of the landfill. Table 8 contains concentrations of siloxanes in the tested landfill gas.

Similarly, as a result of a high flow, the sorbent could fail to capture the silicon compounds or it could be saturated with these substances.

Table 7. Instrument and standard specification [13]

\begin{tabular}{|c|c|c|c|c|}
\hline \multicolumn{2}{|c|}{ GC/FID method } & \multirow{2}{*}{$\begin{array}{c}\text { Unit } \\
{ }^{\circ} \mathrm{C}\end{array}$} & \multirow{2}{*}{$\begin{array}{c}\text { D4, D5, L2, L3 } \\
110\end{array}$} & \multirow{2}{*}{\begin{tabular}{|l|} 
D3 \\
240
\end{tabular}} \\
\hline Dispenser & Dispenser temperature & & & \\
\hline & Splitless & Yes/No & Yes & Yes \\
\hline \multirow[t]{2}{*}{ Column } & Flow & $\mathrm{mL} / \mathrm{min}$ & 4 & 4 \\
\hline & Initiation temperature & ${ }^{\circ} \mathrm{C}$ & $40 / \min$ & 45/maintains $5 \mathrm{mir}$ \\
\hline \multirow[t]{3}{*}{ Furnace } & Temperature change & ${ }^{\circ} \mathrm{C} / \mathrm{min}$ & 15 & 25 \\
\hline & Final temperature & ${ }^{\circ} \mathrm{C}$ & 240 & 250 \\
\hline & Max. furnace temp. & ${ }^{\circ} \mathrm{C}$ & 325 & 325 \\
\hline \multirow[t]{2}{*}{ Autosampler } & Injection volume & $\mu 1$ & 1 & 1 \\
\hline & Detector temperature & ${ }^{\circ} \mathrm{C}$ & 300 & 300 \\
\hline \multirow[t]{3}{*}{ Detector } & Air flow & $\mathrm{mL} / \mathrm{min}$ & 400 & 400 \\
\hline & Hydrogen flow & $\mathrm{mL} / \mathrm{min}$ & 30 & 30 \\
\hline & Carrier gas flow & $\mathrm{mL} / \mathrm{min}$ & 15 & 30 \\
\hline
\end{tabular}


Kaszubska \& Wzorek / Int. J. of Thermal \& Environmental Engineering, 16 (2018) 91-96

Table 8. Obtained concentrations of siloxanes in the investigated landfill gas

\begin{tabular}{|c|c|c|c|c|c|c|c|}
\hline & $\begin{array}{c}\text { Sampling } \\
\text { time }\end{array}$ & Flow & L3 & D4 & D5 & D3 & Total \\
\hline & $\mathrm{h}$ & $\mathrm{L} / \mathrm{h}$ & $\mathrm{mg} / \mathrm{m}^{3}$ & $\mathrm{mg} / \mathrm{m}^{3}$ & $\mathrm{mg} / \mathrm{m}^{3}$ & $\mathrm{mg} / \mathrm{m}^{3}$ & $\mathrm{mg} / \mathrm{m}^{3}$ \\
\hline XAD I & 0.1 & 42 & 0.2520 & 0.1606 & 0.3608 & 0.6327 & 1.0814 \\
\hline XAD II & 0.2 & 42 & 0.2766 & 0.2772 & 0.0618 & 0.4391 & 1.0548 \\
\hline XAD III & 0.3 & 42 & 0.2491 & 0.3096 & 0.0510 & 0.3126 & 0.9223 \\
\hline XAD IV & 0.4 & 42 & 0.1406 & 0.3063 & 0.0413 & 0.2241 & 0.7122 \\
\hline XAD V & 0.5 & 42 & 0.3482 & 1.0704 & 0.1067 & 0.0200 & 1.5453 \\
\hline XAD VI & 0.6 & 42 & 0.2225 & 0.9541 & 0.0683 & 0.2888 & 1.5337 \\
\hline XAD VIII & 0.3 & 135 & 0.0009 & 0.0096 & 0.0043 & ND & 0.0154 \\
\hline XAD IX & 0.4 & 135 & 0.0091 & 0.0211 & 0.0080 & ND & 0.0347 \\
\hline XAD X & 0.6 & 135 & 0.0010 & 0.0115 & 0.0050 & ND & 0.0106 \\
\hline
\end{tabular}

$* \mathrm{ND}$ - not detected

During the determined flow, with increased sampling time, there is a drop in the total concentration of siloxanes. This dependence occurs if the sampling time is extended from $0.1 \mathrm{~h}$ to $0.4 \mathrm{~h}$. Whereas above this value, the total count of siloxanes increases and reaches is peak count at the sampling time of $0.5 \mathrm{~h}$ (Fig. 3).

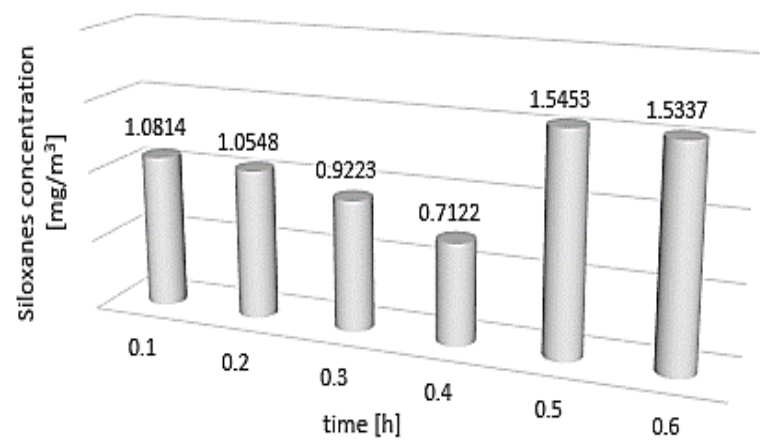

Fig. 3. Change of the siloxanes concentration depending on the sampling time

\section{Conclusion}

The landfill gas obtained at the Municipal Landfill in Opole in Poland is contaminated with a low amount of siloxanes. The adsorptive siloxane sampling method and gas chromatographic analysis coupled with the flame ionization detection allowed to determine the following silicon compounds in the examined landfill biogas: D4, D3, L3 and D5. A series of sampling activities was performed varying in terms of their sampling time and biogas flow through the sorbent. The analysis of results allowed to distinct the most advantageous sampling conditions, i.e. low biogas flow of ca. $40 \mathrm{~L} / \mathrm{h}$ with sampling time of $0.5 \mathrm{~h}$. The total siloxane counts in the examined biogas are so low that their effect on the power devices of the bio-power plant located in the landfill area is negligible, whereas attempts of biogas treatment would be too expensive in relation to the damage caused by them.

\section{References}

[1] Rasi S., Veijanen A., Rintala J. Trace compounds of biogas from different biogas production plants. Energy, 2007. 32(8), p. 1375-1380. DOI:10.1016/j.energy.2006.10.018
[2] Gaj K., Ciołek J., Pakuluk A., Steininger M. Siloxanes in biogas - origin, hazards and analytical problems, Gaz, Woda i Technika Sanitarna, 2014, p. 394-397.

[3] Wang, D.G., Norwood, W., Alaee, M. Review of recent advances in research on the toxicity, detection, occurrence and fate of cyclic volatile methyl siloxanes in the environment. Chemosphere, 2013. Vol. 93/5, p. 711-725,

DOI: 10.1016/j.chemosphere.2012.10.041

[4] Arnold, M. Reduction and monitoring of biogas trace compounds. SVTT Tiedotteita - Research Notes 2496 (2009)

[5] Stanuch I., Biegańska J. Siloksany w biogazie, Archiwum Gospodarki Odpadami i Ochrony Środowiska, Politechnika Śląska, Gliwice (2014).

[6] Rasi, S., Lehtinen, J., Rintala J. Determination of organic silicon compounds in biogas from wastewater treatments plants, landfills, and co-digestion plants. Renew. Energ., 2010, Vol. 35, p. 2666-2673. DOI: 10.1016/j.renene.2010.04.012

[7] Lunghi, P., Bove, R., Desideri, U. Life-cycleassessment of fuel cells based landfill-gas energy conversion technologies. J. Power Sources, 2004 Vol. 131, p. 120-126. DOI:10.1016/j.jpowsour.2004.01.006

[8] Pierce, J. Siloxane quantification, removal and impact on landfill gas utilization facilities. 8th Annual LMOP Conference January 10-11, Baltimore, Maryland, (2005)

[9] Tansel, B., Surita, S.C. Selectivity and limitations of carbon sorption tubes for capturing siloxanes in biogas during field sampling. Waste Manage., 2016. Vol. $52, \quad$ p. $122-129$. DOI: 10.1016/j.wasman.2016.03.057

[10] Szlęk, M. Światowe trendy analityczne w oznaczaniu składników śladowych zawartych w biogazie. Instytut Nafty i Gazu, Nafta - Gaz, 2015. Vol. 11, p. 821-826.

[11] Accettola F., M. Guebitz G., Schoeftner R. Siloxane removal from biogas by biofiltration: biodegradation studies. Clean Techn. Environ. Policy, 2008. Vol. 10, p. 211-218. DOI 10.1007/s10098-007-0141-4 
[12] Surita SC., Tansel B. Preliminary investigation to characterize deposits forming during combustion of biogas from anaerobic digesters and landfills. Renew. Energ, 2015. Vol. 80, p. 674-681. DOI.: 10.1016/j.renene.2015.02.060

[13] Kaszubska M., Wzorek M. Analiza związków krzemoorganicznych w biogazie. IX Interdyscyplinarna Konferencja Naukowa TYGIEL, March 18-19, Lublin, Poland (2017)

[14] Dewil R., Appels L., Baeyens J. Energy use of biogas hampered by the presence of siloxanes. Energ. Convers. Manage., 2006, Vol. 47, p. 1711-1722. DOI 10.1016/j.enconman.2005.10.016

[15] Saeed S., et al. Comparison of impinger and canister methods for the determination of siloxanes in air.
AWMA Symposium on air quality measurement methods and Technology, San Francisco (2002)

[16] Pakuluk A., Ciołek J. Problemy z siloksanami w instalacjach biogazowych. Zagrożenia stwarzane przez spalanie biogazu zawierającego organiczne związki krzemu, Instal, 2013. Vol. 9, p. 483-490

[17] Wheless E., Pierce J. Siloxanes in landfill and digester gas update. SWANA's 27th Annual Landfill Gas Symposium, San Antonio, Texas (2004)

[18] Arnold M., Kajolinna, T. Development of on-line measurement techniques for siloxanes and other trace compounds in biogas, Waste Manage. 2010, Vol. 30(6), p. 1011-7. 10.1016/j.wasman.2009.11.030 